\title{
Land Suitability Assessment for Maize and Paddy Production in Bogur Microwatershed Using Remote Sensing and GIS Techniques
}

\author{
Denis Magnus Ken Amara ${ }^{1}$, Philip J. Kamanda ${ }^{2}$, Parameshgouda L. Patil ${ }^{3}$, Augustine M. \\ Kamara $^{4}$ \\ ${ }^{1}$ Department of Soil Science, School of Agriculture, Njala Campus, Njala University, Sierra Leone \\ ${ }^{2 \& 4}$ Department of Extension \& Rural Sociology, School of Agriculture, Njala Campus, Njala University, Sierra Leone \\ ${ }^{3}$ Department of Soil Science \& Agricultural Chemistry, College of Agriculture, University of Agricultural Sciences, Dharwad, \\ 580005, Karnataka, India \\ * Corresponding author: Dr. Denis. M. K. Amara, Department of Soil Science, School of Agriculture, Njala \\ University, Sierra Leone. E-mail: denismken@yahoo.com. Tel: +23279905400
}

\begin{abstract}
The main aim of this study was to assess the soils of Bogur microwatershed in Northern Transition Zone of Karnataka for sustainable production of maize and paddy. Seven land qualities including water availability index $(W)$, oxygen availability $(O)$, nutrient availability index (NAI), water retention (I), rooting conditions $(R)$, excess of salts $(\mathrm{Sa})$ and topography $(T)$ were selected and their suitability evaluated. Four soils series: Singhanhalli, Bogur, Mugli and Venkatapur and seventeen soil units including SGH-c-d4-Be1 belonging to Singhanhalli series; MGL-cl-d3-De2 belonging to Mugli series; BGR1-sl-d4Ce2, BGR2-c-d5-Be1, BGR3-sl-d4-Ce3 and BGR4-cl-d5$\mathrm{Ce} 2$ belonging to Bogur series; and VKP1-sc-d4-Ce2, VKP2-sl-d3-Ee4, VKP3-c-d5-Be1, VKP4-sl-d2-Be1, VKP5scl-d4-De3, VKP5-scl-d3-De2, Vkp5-scl-d4-Be2, VKP5-scld3-Ce2, VKP6-cl-d4-Ce2, VKP7-sl-d2-De3, and VKP8-sld4-De3 belonging to Venkatapur series, were identified. Singhanhalli series covers 78.5 ha (10.3\%); Mugli series covers 22.1 ha (2.9\%); Bogur series covers 237.3 ha (31.2\%); and Venkatapur series covers 406.6 ha (53.5\%). One mapping unit, VKP2-sl-d3-Ee4 which accounts for 10.2 ha (1.3\%) of the study area, was not evaluated for crop production because it is a non-cultivable land. The results revealed that 33.8 ha (4.4\%) is moderately suitable, 312.7 ha $(41.1 \%)$ is marginally suitable and 387.7 ha (51\%) is not suitable for maize; whereas for paddy, all sixteen mapping units which account for about 734.2 ha (96.5\%) of study area is marginally suitable. These results could be used as baseline information needed for mapping specific soil resource constraints for sustainable production of these crops in the study area.
\end{abstract}

Keywords_- Land suitability, maize, paddy, GIS, India, Denis.

\section{INTRODUCTION}

Efficient management of natural resources is essential for ensuring food supplies and sustainability in agricultural development. The task of meeting the food demand of the growing population without affecting the ecological assets for future generations is being given top priority by both scientists and planners. On the one hand, there is an urgent need to match the land resources with current land uses for sustainable production and to meet the needs of society, while conserving fragile ecosystems [1]. On the other hand, the management and analysis of large volumes of spatial data require the use of geographic information system (GIS), for solving complex geographical and hydrological problems [2]. The GIS technology is designed to allow users to collect, manage, analyze, and retrieve large volumes of spatially referenced data collected from a variety of sources [3]. Traditionally, data management ability has generally been limited for two reasons: 1) difficulty in acquiring useful information over vast areas and 2) lack of a means for effective processing and analysis of the acquired data [4]. Due to the many factors that are associated with each feature under study, the costs of analysis and manipulation with manual methods are prohibitive. Besides, they consume too much time on the one hand and are practically impossible on the other hand. Today, land suitability is assessed through advanced computer programs including decision support systems, GIS and remote sensing (RS), which contribute to effective 
and efficient planning process and allow access to large amounts of useful information quickly. Especially during the last decade, remote sensing and GIS technology has received much attention in applications related to land evaluation and resource management on large spatial scales $[5,6]$. GIS has become a powerful tool for management and analysis of the data required for any land development activity.

Land suitability assessment is a prerequisite to achieve optimum utilization of available land resources for agricultural production in a sustainable manner. [7] defined land suitability as 'a function of crop requirements and land characteristics as well as a measure of how well the qualities of a land unit matches the requirements of a particular form of land use'. Land suitability assessment allows identifying the main limiting factors of a piece of land for a particular crop production and enables decision makers to develop a crop management system for increasing the land productivity.

In India, rice and maize are two main food crops, but their yields are far below their agronomic and genetic potential mainly due to soil infertility. There has been report of widespread land degradation and soil infertility due to deficiencies of both macro and micronutrients in many parts of the country. In Bogur microwatershed, crops yields have been declining due to poor farming methods, land degradation and insufficiency of soil nutrients [8]. Rapid development and population growth in this part of India have led to increasing human demands for land as well as food crops like rice, maize and vegetables among others. In response to this, so many land uses are evident in the area, among which agricultural land use is most notable apart from residential. From field observations, the crops grown in the area are rice, maize, millet, sorghum, groundnut, chickpea and vegetables with very few farmers growing either rice or maize compared to other crops. In a study conducted by [9] to assess the biophysical constraints of soils of the study area, it was revealed that the soil health status ranged from poor $(31.1 \%)$ to medium $(68.9 \%)$ due to moderate to severe soil physical constraints resulting from shallow depth, poor aggregate stability, moderately developed tillage pan, high content of coarse fragments and low organic matter. The results of the study indicated that more information is needed on soil qualities and conditions of the area, as well as the fertility status of the soil, to assess both physical and chemical properties of the soils for cultivation of major crops in the study area. Hence, this study will assist in identifying soils in order to optimize the yields of maize and paddy in the study area. The information obtained will help in formulating meaningful guidelines in ensuring the sustainability of agricultural practice not only in the study area, but the entire Northern Transition Zone 8 region of India. Keeping this in view, this study is envisaged to assess the suitability of the study area for two major cereal crops: maize and paddy using a Remote Sensing and GIS approach. This research work will provide information at local level which could be utilized by farmers for selecting appropriate lands for growing these crops in order to overcome the major production constraints. The specific objectives of the study are to:

1. Identify the land quality requirement (physical and chemical properties of soils) for rice and maize cultivation.

2. Assess the land quality (fertility status of soils) of the study area in relation to rice and maize cultivation.

3. Prepare land suitability maps which provide information that will assist farmers and other land users in identifying areas with constraints for rice and maize cultivation.

\section{MATERIALS AND METHODS}

\subsection{Description of study Area}

Bogur micro-watershed (Fig. 1), is located in the hot semiarid agro-ecological region of India between latitude $15.60^{\circ}$ to $15.70^{\circ} \mathrm{N}$ and longitude $74.97^{\circ}$ to $74.98^{\circ} \mathrm{E}$ in the Dharwad taluk of Dharwad district in the northern transition zone of Karnataka state. 


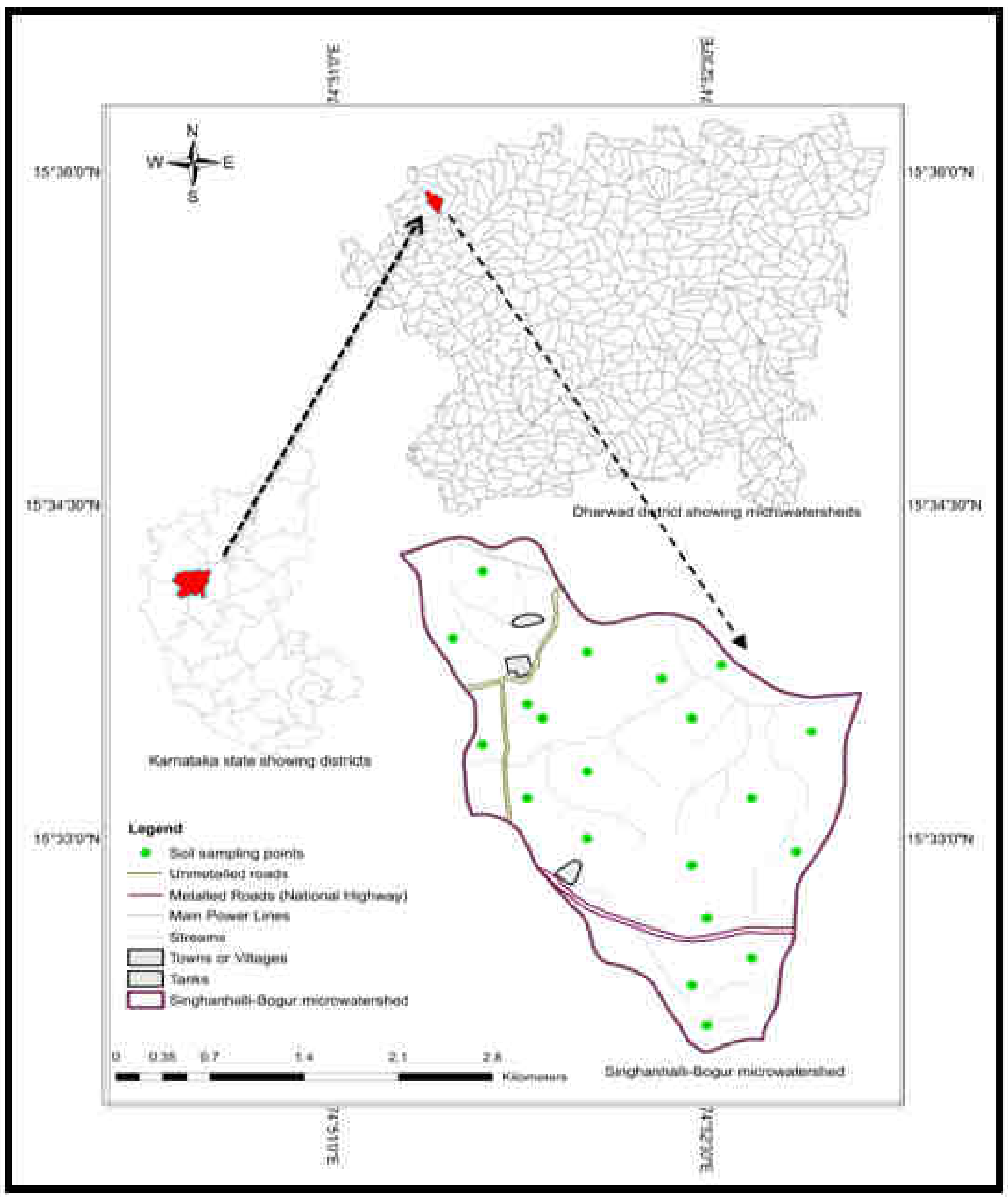

Fig. 1: Map showing study area

It has an area of 760.6 ha, with a medium to high available water content and a length of growing period of 150-180 days. The climate is characterized by hot and humid summer and mild and dry winter. The average annual rainfall is $755.2 \mathrm{~mm}$, which is distributed over May to October and annual temperature ranges from $24-28{ }^{\circ} \mathrm{C}$ with an Ustic soil moisture and Isohyperthermic soil temperature regimes [8]. The highest elevation in this area is $754 \mathrm{~m}$ above mean sea level while the relief is very gently to strongly sloping. The general slope is towards the northeast, southeast and southwest but it is more in the southwest direction. The drainage pattern is parallel. The soils are derived from chlorite schist with shale as dominant parent material containing banded iron oxide quartzite concretions. 
This characteristic feature makes the soils coarse textured and shallow at the higher elevations but gradually, fineness and depth of soil increases towards the lower elevations. Black and red soils are the main soil types but the red soils are in much higher proportion than the black soils. The natural vegetation mainly comprised of trees and shrubs including Acacia (Acacia auruculiformis), Neem (Azadirachta indica) and Eucalyptus (Eucalyptus sideroxylon and Eucalyptus regnana).

\subsection{Soil Survey and Classification}

A detailed soil survey of the study area was carried out as per procedure outlined by [10] using IRS P6 LISS-IV satellite image and Toposheet of Karnataka. The area was intensively traversed and 20 pedon locations were fixed based on soil heterogeneity. At each pedon location, a fresh profile was opened for soil characterization and horizonwise soil samples were collected and analyzed for important physical and physicochemical properties following standard analytical procedures. After the correlation of soil properties, soils were classified into four series according to "Keys to Soil Taxonomy" [11] (Table $1 \& 2$ ).

Table.1: Physical characteristics of soil series in Bogur microwatershed

\begin{tabular}{|c|c|c|c|c|c|c|c|}
\hline \multirow{2}{*}{ Soil Series } & \multicolumn{7}{|c|}{ Physical Characteristics } \\
\hline & Slope & Erosion & Drainage & Permeability & Depth & Texture & $\begin{array}{c}\text { Coarse fragments } \\
(\%)\end{array}$ \\
\hline Singhanhalli & Very gently sloping & Slight & Well drained & Moderately rapid & Deep & $\mathrm{c}$ & 5.2 \\
\hline Bogur & Gently sloping & Moderate & Well drained & Rapid & Very deep & gscl & 35.7 \\
\hline
\end{tabular}

Table.2: Chemical characteristics of soil series in Bogur microwatershed

\begin{tabular}{|c|c|c|c|c|c|c|}
\hline \multirow[b]{2}{*}{ Soil Series } & \multicolumn{6}{|c|}{ Soil chemical properties } \\
\hline & pH & $\begin{array}{c}\mathrm{OC}^{*} \\
\left(\mathrm{~g} \mathrm{~kg}^{-1}\right)\end{array}$ & $\begin{array}{c}\mathrm{CaCO}_{3} \\
(\%)\end{array}$ & $\begin{array}{c}\mathrm{EC}^{\varphi} \\
\left(\mathrm{dS} \mathrm{m^{-1 }}\right)\end{array}$ & $\begin{array}{c}\mathrm{CEC}^{\S} \\
(\mathrm{cmol}(\mathrm{p}+) / \mathrm{kg})\end{array}$ & $\begin{array}{l}\mathrm{BS}^{\phi} \\
(\%)\end{array}$ \\
\hline Singhanhalli & 7.7 & 4.4 & 2.4 & 0.1 & 34.9 & 75.8 \\
\hline Mugli & 6.5 & 8.6 & 8.0 & 0.1 & 18.3 & 64.8 \\
\hline Bogur & 7.1 & 4.7 & 5.4 & 0.1 & 25.1 & 68.1 \\
\hline Venkatapur & 6.6 & 9.7 & 2.0 & 0.1 & 28.2 & 58.3 \\
\hline
\end{tabular}

* = Organic carbon; $\varphi=$ Electrical conductivity; $\S=$ Cation Exchange Capacity; $\phi=$ Base Saturation

\subsection{Land suitability evaluation}

\subsubsection{Defining land suitability attributes}

In the present study, seven land qualities essential for sustainable maize and paddy production including water availability index (W), oxygen availability $(\mathrm{O})$, nutrient availability index (NAI), water retention (I), rooting conditions (R), excess of salts (Sa) and topography $(\mathrm{T})$ were selected and their suitability for sustainable production of rice and maize were assessed, based on the guidelines of [12] and [13]. After that, matching of land qualities (Table 1 \& 2) with land use requirements (crop criteria) (Table $3 \&$ 4) was undertaken during which each of the land qualities was rated by assigning numerical values ranging from 0.81 - 1.0, $0.41-0.8,0.11-0.4$ and $0.01-0.1$ for highly suitable (S1), moderately suitable (S2), marginally suitable (S3) and not suitable $(\mathrm{N})$, respectively.
Below is an outline of the methodology followed for evaluating the suitability of the study area for maize and paddy production:

- Water Availability Index (W): Water availability index was assessed based on an annual rainfall cumulative total of 10 years (2001--2011) and the values were interpolated by Krigging analysis. The spatial ' $W$ ' layer was then divided into 4 suitability classes as proposed by [14].

- Oxygen Availability (O): Oxygen availability was assessed from the soil drainage data which was collected from the study area and a spatial ' $\mathrm{O}$ ' layer was created from the data by characterizing the data into 4 suitability classes as defined by [14, $15]$. 
- $\quad$ Nutrient Availability Index (NAI): The 'NAI' layer is a spatial layer that consists of nitrogen $(\mathrm{N})$, phosphorus $(\mathrm{P})$, potassium $(\mathrm{K})$ and soil $\mathrm{pH}(\mathrm{pH})$. This layer was created through an overlay process in the ArcGIS environment using the method developed by [16].

- $\quad$ Rooting Conditions (R): The spatial ' $\mathrm{R}$ ' layer was created from the data collected on soil depth by dividing the data into 4 suitability classes as defined by [14, 17].

- Water Retention (I): The spatial 'I' layer was created from soil texture data by dividing the data into 4 suitability classes as defined by [14].

- Excess of Salts $(\mathrm{Sa})$ : The status of soil salinity on crops was assessed based on the concentration of soluble salts and the spatial 'Sa' layer was created by defining the data into suitability classes as suggested by [18].

- $\quad$ Topography $(T)$ : The spatial ' $\mathrm{T}$ ' layer was created through Matrix Convolution programming using landform and slope as input parameters by following the method recommended by [14].

\subsubsection{Integration of land suitability attributes into a} parametric equation

Land suitability was evaluated by integrating the selected seven land attributes into a parametric equation as given below:

$$
\mathrm{S}_{(1,2,3, \mathrm{~N})}=\mathrm{W} * \mathrm{O} * \mathrm{NAI} * \mathrm{R} * \mathrm{I} * \mathrm{Sa} * \mathrm{~T}
$$

Where $\mathrm{S}=$ Overall suitability; divided into highly suitable $\left(S_{1}\right)$, moderately suitable $\left(S_{2}\right)$, marginally suitable $\left(\mathrm{S}_{3}\right)$ and not suitable $(\mathrm{N})$

$\mathrm{W}=$ water availability index $(\mathrm{W})$,

$\mathrm{O}=$ oxygen availability $(\mathrm{O})$,

$\mathrm{NAI}=$ nutrient availability index $(\mathrm{NAI})$,

I = water retention $(\mathrm{I})$,

$\mathrm{R} \quad=$ rooting conditions $(\mathrm{R})$,

$\mathrm{Sa}=$ excess of salts $(\mathrm{Sa})$ and

$\mathrm{T}=$ topography $(\mathrm{T})$.

The flow chart of methodology for land suitability evaluation in study area is given in Figure 2.

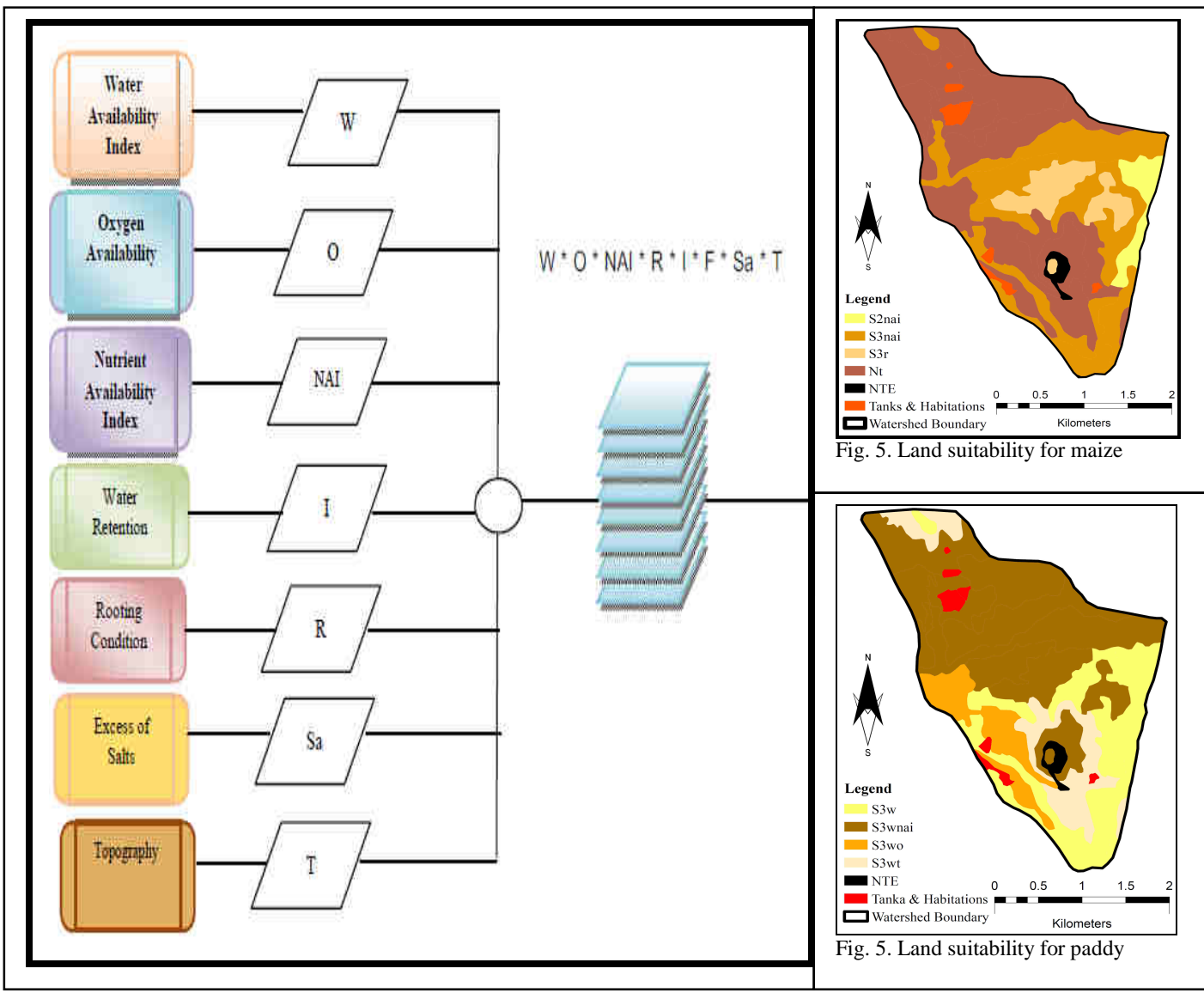

Fig. 2: Flow chart of methodology for land suitability evaluation in Bogur microwatershed 
Table.3: Land use requirement (crop criteria) for maize

\begin{tabular}{|c|c|c|c|c|c|c|}
\hline \multicolumn{3}{|c|}{ Land use requirement (Crop criteria) } & \multicolumn{4}{|c|}{ Suitability factor rating/interpretation } \\
\hline Land quality & $\begin{array}{l}\text { Diagnostic } \\
\text { factor }\end{array}$ & Unit & $\begin{array}{c}\text { S1 } \\
(0.81-1.0)\end{array}$ & $\begin{array}{c}\text { S2 } \\
(0.41-0.8)\end{array}$ & $\begin{array}{c}\mathrm{S3} \\
(\mathbf{0 . 1 1 - 0 . 4 )}\end{array}$ & $\begin{array}{c}\mathrm{N} \\
(0.01-0.10)\end{array}$ \\
\hline $\begin{array}{l}\text { Water Availability Index } \\
\text { (W) }\end{array}$ & Annual Rainfall & $\mathrm{mm}$ & $900-1000$ & $750-900$ & $500-750$ & $<500$ \\
\hline Oxygen Availability $(\mathrm{O})$ & Soil Drainage & class & well drained & mod. to imperfect & $\begin{array}{c}\text { poor/ } \\
\text { excessive }\end{array}$ & very poor \\
\hline \multirow{6}{*}{$\begin{array}{l}\text { Nutrient Availability Index } \\
\text { (NAI) }\end{array}$} & $\mathrm{NAI}=\mathrm{N} * \mathrm{P} * \mathrm{~K} * \mathrm{pH}$ & - & $>0.160$ & $0.026-0.160$ & $0.003-0.026$ & $<0.003$ \\
\hline & Available N & $\mathrm{kg} \mathrm{ha}_{1}^{-}$ & $>560$ & $280-560$ & $100-280$ & $<100$ \\
\hline & Available P & $\mathrm{kg} \mathrm{ha}_{1}^{-}$ & $>50$ & $20-50$ & $10-20$ & $<10$ \\
\hline & Available K & $\mathrm{kg} \mathrm{ha}_{1}^{-}$ & $>280$ & $120-280$ & $75-110$ & $<75$ \\
\hline & $\mathrm{pH}$ & - & $5.5-7.5$ & $7.6-8.5$ & $8.6-9.0$ & $>9.0$ \\
\hline & & & & $5.0-5.4$ & $5.0-4.0$ & $<4.0$ \\
\hline Water Retention (I) & Soil Texture & - & $\begin{array}{l}\mathrm{L}, \mathrm{CL}, \mathrm{SCL}, \\
\text { SiL }\end{array}$ & $\begin{array}{c}\text { SL, SiCL, SiC, } \\
\text { C(non-swelling) }\end{array}$ & $\begin{array}{l}\text { C (shrink- } \\
\text { swell), LS }\end{array}$ & $S, G$ \\
\hline Rooting Conditions (R) & Soil Depth & $\mathrm{cm}$ & $>75$ & $50-75$ & $25-50$ & $<25$ \\
\hline Excess of Salts (Sa) & Soil Salinity & class & non saline & low & medium & High \\
\hline Topography (t) & Slope & $\%$ & $<3$ & $3-5$ & $5-8$ & $>8$ \\
\hline
\end{tabular}

(Source: Modified from [13])

* Remark: CL=Clay Loam, $\mathrm{SiC}=$ Silty Clay, $\mathrm{SiCL}=$ Silty Clay Loam, C = Clay, L = Loam, SiL = Silty Loam, LS = Loamy Sand, SCL = Sandy Clay Loam, SL= Sandy Loam, $\mathrm{S}=$ Sand, G = Gravel Soil.

Table.4: Land use requirement (crop criteria) for rice (paddy)

\begin{tabular}{|c|c|c|c|c|c|c|}
\hline \multicolumn{3}{|c|}{ Land Use Requirement (Crop criteria) } & \multicolumn{4}{|c|}{ Suitability Factor Rating/Interpretation } \\
\hline Land quality & $\begin{array}{l}\text { Diagnostic } \\
\text { factor }\end{array}$ & Unit & $\begin{array}{c}\text { S1 } \\
(0.81-1.0)\end{array}$ & $\begin{array}{c}\mathrm{S2} \\
(0.41-0.8)\end{array}$ & $\begin{array}{c}\mathrm{S3} \\
(0.11-0.4)\end{array}$ & $\begin{array}{c}\mathrm{N} \\
(0.01-0.10)\end{array}$ \\
\hline $\begin{array}{l}\text { Water Availability Index } \\
\text { (W) }\end{array}$ & Annual Rainfall & $\mathrm{mm}$ & $>1500$ & $1100-1500$ & $800-1100$ & $<800$ \\
\hline Oxygen Availability $(\mathrm{O})$ & Soil Drainage & class & poor, very poor & $\begin{array}{l}\text { Somewhat } \\
\text { poor }\end{array}$ & mod. well & $\begin{array}{l}\text { well, very } \\
\text { well }\end{array}$ \\
\hline Nutrient Availability Index & $\mathrm{NAI}=\mathrm{N} * \mathrm{P} * \mathrm{~K} * \mathrm{pH}$ & - & $>0.160$ & $0.026-0.160$ & $0.003-0.026$ & $<0.003$ \\
\hline (NAI) & $\mathrm{N}$ & $\%$ & $>0.5$ & $0.08-0.5$ & $0.04-0.08$ & $<0.04$ \\
\hline & $\mathrm{P}$ & ppm & $>50$ & $25-50$ & $10-25$ & $<10$ \\
\hline & $\mathrm{K}$ & ppm & $>60$ & $30-60$ & $<30$ & - \\
\hline & $\mathrm{pH}$ & - & $5.6-7.3$ & $7.4-7.8$ & 7.9-8.4 & $>8.4$ \\
\hline & & & & $4.5-5.5$ & $4.0-4.5$ & $<4.0$ \\
\hline Water Retention (I) & Soil Texture & - & CL, SiC, SiCL, C & $\mathrm{L}, \mathrm{SiL}$ & LS, SCL, SL & $S, G$ \\
\hline Rooting Conditions (R) & Soil Depth & $\mathrm{cm}$ & $>50$ & $25-50$ & $15-25$ & $<15$ \\
\hline Excess of Salts (Sa) & Soil Salinity & class & non saline & low & medium & High \\
\hline Topography (t) & Slope & $\%$ & $0-1$ & $1-3$ & $3-5$ & $>5$ \\
\hline
\end{tabular}

(Source: Modified from [13])

* Remark: CL=Clay Loam, $\mathrm{SiC}=$ Silty Clay, $\mathrm{SiCL}=$ Silty Clay Loam, C = Clay, L = Loam, SiL = Silty Loam, 
LS = Loamy Sand, SCL = Sandy Clay Loam, SL= Sandy Loam, S = Sand, G = Gravel Soil.

\section{RESULTS AND DISCUSSION}

\subsection{Soil series and soil mapping units of Bogur} microwatershed

The nature of soils and their spatial representation in the study area is depicted in Fig. $3 \&$ 4. Four soils series, viz, Singhanhalli, Bogur, Mugli and Venkatapur series are shown in Fig. 3 and seventeen soil units are shown in Fig. 4.

Singhanhalli series, which covers 78.5 ha $(10.3 \%)$, is classified as Typic Haplusterts. This series contain deep, well-drained clay soils that are located on very gentle slopes found in lowlands, associated with moderate to rapid permeability and slight erosion. Mugli series, which covers 22.1 ha $(2.9 \%)$, is classified as Ultic Haplustalfs. These soils are moderately deep and well-drained clay loam soils that are located on moderate slopes found in undulating midlands, associated with moderate to rapid permeability and moderate erosion. Bogur series covers 237.3 ha $(31.2 \%)$. Soils of this series were classified into three families, namely, Typic Ustorthents, Typic Calciusterts and Ultic Haplustalfs. The Typic Ustorthents are deep and welldrained sandy loam soils that are located on gentle slopes found in undulating midlands, associated with rapid permeability and moderate erosion. The Typic Calciusterts are very deep, moderately drained clay soils that are located on very gentle slopes found in lowlands, associated with slow permeability and slight erosion; while the Ultic Haplustalfs are very deep, well-drained clay loam soils that are located on gentle slopes found in lowlands, associated with rapid permeability and moderate erosion. Overall, soils of Bogur series are deep, well drained, sandy clay loam soil that are located on gentle slopes found in lowlands and undulating midlands, associated with rapid permeability and moderate erosion.

Venkatapur series covers 406.6 ha $(53.5 \%)$. Soils of this series were classified into six families, namely, Typic Ustorthents, Typic Ustipsamments, Chromic Haplusterts, Typic Haplustalfs, Ultic Haplustalfs and Lithic Haplustalfs. The Typic Ustorthents are deep and well-drained sandy clay soils that are located on gentle slopes found in lowlands, associated with slow permeability and moderate erosion. The Typic Ustipsamments are deep and well-drained sandy loam soils that are located on steep slopes found in uplands, associated with rapid permeability and very severe erosion. The Chromic Haplusterts are deep and moderately drained clay soils that are located on very gentle slopes found in lowlands, associated with moderate to rapid permeability and slight erosion. The Typic Haplustalfs are shallow and well-drained sandy loam soils that are located on very gentle slopes found in uplands, associated with moderate to rapid permeability and slight erosion. The Ultic Haplustalfs are moderately deep to deep, moderately drained to welldrained clay loams and sandy clay loam soils that are located on very gentle and gentle to moderate slopes found in lowlands and undulating midlands, associated with moderate to rapid permeability and moderate to severe erosion. The Lithic Haplustalfs are shallow, well-drained sandy loam soils that are located on moderate slopes found in uplands, associated with moderate to rapid permeability and severe erosion. Overall, soils of the Venkatapur series are deep, well drained, sandy clay loam soils that are located on gentle slopes found in lowlands, undulating midlands and uplands, associated with moderate to rapid permeability and moderate erosion.

\subsection{Soil mapping units}

A soil map is designed to show the distribution of soil types and mapping units in relation to other prominent physical and cultural features of the earth surface. The first step that succeeded the soil survey was the establishment of the units of classification that could be shown on a map. Such maps (Fig. $3 \& 4$ ) contain interpretative information for land users. The mapping units of soils are phases of soil series considering texture, depth, slope and erosion characteristics of the site. Four soil series were identified in the study area and named after four villages, viz., Singhanhalli (SGH), Bogur (BGR), Mugli (MGL) and Venkatapur (VKP) series (Fig. 3). In the identification of soil mapping units, soil series, soil texture, soil depth, slope and erosion were incorporated as inputting parameters. The input parameters and how they fit into the mapping unit symbols are discussed below:

\section{Soil series class}

Two pedons (pedon 1 and 2) belonged to Singhanhalli (SGH) series with a single phase; six pedons (pedon 3, 4, 8, 9, 10 and 11) belonged to Bogur (BGR) series with four phases; pedon 15 belonged to Mugli (MGL) series with a single phase and eleven pedons (pedon 5, 6, 7, 12, 13, 14, 16, 17, 18, 19 and 20) belonged to Venkatapur (VPK) series with eight phases.

\section{Soil texture class}

The texture of five pedons (pedon 1, 2, 3, 4 and 6) was clayey, seven pedons (pedon 5, 8, 9, 10, 17, 19 and 20) were sandy loam, three pedons (pedon 11, 13 and 15) were 
clay loam, pedon 12 was sandy clay and four pedons (pedon $7,14,16$ and 18) were sandy clay loam.

\section{Soil depth class}

The depth of two pedons (pedon 5 and 19) was shallow but was not indicated in the taxonomy because they were not Histosols, four pedons (pedon 14, 15, 17 and 18) were moderately deep, ten pedons (pedon 1, 2, 7, 8, 9, 10, 12, 13, 16 and 20) were deep and four pedons (pedon 3, 4, 6 and 11) were very deep.

\section{Slope class}

The slope of seven pedons (pedon 1, 2, 3, 4, 5, 6 and 7) were very gently sloping (slope class B), seven pedons (pedon 8, 9, 10, 11, 12, 13 and 14) were gently sloping (slope class C), five pedons (pedon 15, 16, 18, 19 and 20) were moderately sloping (slope class D) and pedon 17 was strongly sloping (slope class E).

\section{Erosion class}

Seven pedons (pedon 1, 2, 3, 4, 5, 6 and 13) were slightly eroded (erosion class e1), seven pedons (pedon 7, 11, 12, $14,15,16$ and 18) were moderately eroded (erosion class e2), five pedons (pedon 8, 9, 10, 19 and 20) were severely eroded (erosion class e3), and pedon 17 was very severely eroded (erosion class e4).

After the integration of the above parameters, seventeen soil mapping units were finalized and these are: SGH-c-d4-Be1 belonging to Singhanhalli series; MGL-cl-d3-De2 belonging to Mugli series; BGR1-sl-d4-Ce2, BGR2-c-d5Be1, BGR3-sl-d4-Ce3 and BGR4-cl-d5-Ce2 belonging to Bogur series; and VKP1-sc-d4-Ce2, VKP2-s1-d3-Ee4, -cd5-Be1, VKP4-sl-d2-Be1, VKP5-scl-d4-De3, VKP3VKP5scl-d3-De2, Vkp5-scl-d4-Be2, VKP5-scl-d3-Ce2,

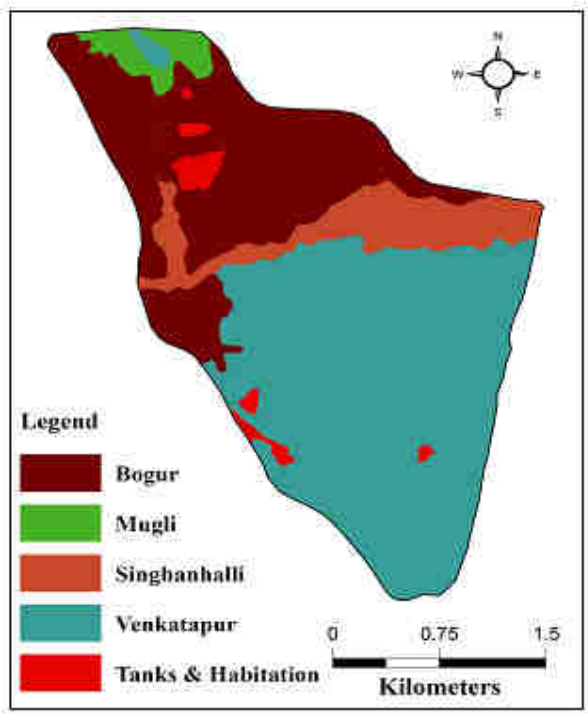

Fig. 3: Soil series map of the study area

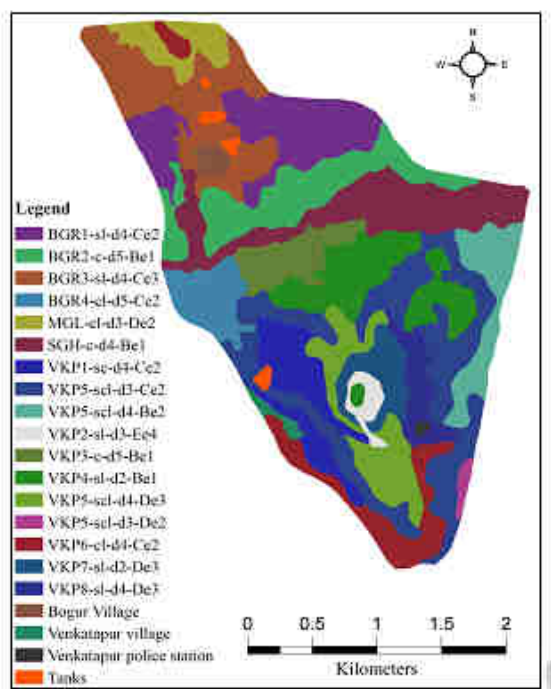

Fig. 4: Soil mapping units of the study area

VKP6-cl-d4-Ce2, VKP7-sl-d2-De3, and VKP8-sl-d4-De3 belonging to Venkatapur series.

\subsection{Land suitability for maize and paddy production}

Globally, maize is one of the most important cereals; and physiologically, maize is one of the most efficient crop species domesticated by man with high yield potential. In India, about 35 per cent of the maize produced is used for human consumption, 25 per cent for poultry and cattle feed, and 15 per cent for food processing and industries. It is projected that India may need 20 million tonnes of maize to meet its requirements for human consumption, piggery, pharma-industry and fodder by 2020 [19]. Similarly, rice is the staple food for more than 60 per cent of the world's population. About 90 per cent of rice grown in the world is produced and consumed in the Asian region [20]. Rice is cultivated in almost all the states of India. However, the states having large area under rice are West Bengal, Uttar Pradesh, Madhya Pradesh, Bihar, Orissa, Andhra Pradesh, Assam, Tamil Nadu, Punjab, Maharashtra and Karnataka. In the present study, sixteen soil mapping units were evaluated for their suitability for growing maize and paddy and the results obtained have been presented in Table 6 . One mapping unit, VKP2-sl-d3-Ee4 which accounts for 10.2 ha $(1.3 \%)$ of the study area, is a non-cultivable land and was therefore not evaluated for crop production.

\subsubsection{Maize}

The results (Table 6) revealed that only one mapping unit, VKP5-scl-d4-Be2, having moderate limitations of nutrient availability index, is moderately suitable (S2) for maize. This mapping unit accounts for 33.8 ha $(4.4 \%)$ of the study area. Five mapping units, SGH-c-d4-Be1, VKP3-c-d5-Be1, 
VKP4-sl-d2-Be1, VKP5-scl-d3-Ce2 and VKP6-cl-d4-Ce2, which account for 312.7 ha $(41.1 \%)$ of the study area are marginally suitable (S3) due to moderate to severe limitations ranging nutrient availability index and rooting conditions (soil depth). Among these mapping units, SGHc-d4-Be1, VKP3-c-d5-Be1, VKP5-scl-d3-Ce2 and VKP6cl-d4-Ce2, which account for 253.2 ha (33.3\%) have limitations of nutrient availability index, while VKP4-sl-d2-
Be1, which account for 59.5 ha $(7.8 \%)$ has limitations of rooting conditions (soil depth). On the other hand, ten mapping units including BGR1-sl-d4-Ce2, BGR2-c-d5-Be1, BGR3-sl-d4-Ce3， BGR4-cl-d5-Ce2， MGL-cl-d3-De2, VKP1-sc-d4-Ce2， VKP5-scl-d4-De3， VKP5-scl-d3-De2, VKP7-sl-d2-De3 and VKP8-sl-d4-De3, which account for 387.7 ha $(51.0 \%)$ are not suitable $(\mathrm{N})$ for maize due to severe limitations of topography (Fig. 5).

Table.6: Land suitability for maize

\begin{tabular}{cccc}
\hline Soil mapping unit & Land suitability class & \multicolumn{3}{c}{ Area } \\
\cline { 3 - 4 } Vkp5-scl-d4-Be2 & S2nai & 33.8 & 4.4 \\
\hline SGH-c-d4-Be1 & & & \\
VKP3-c-d5-Be1 & S3nai & 253.2 & \\
VKP5-scl-d3-Ce2 & & & \\
VKP6-cl-d4-Ce2 & & 59.3 \\
\hline VKP4-sl-d2-Be1 & S3r & \\
\hline MGL-cl-d3-De2 & & & \\
BGR1-sl-d4-Ce2 & & & \\
BGR2-c-d5-Be1 & & & \\
BGR3-sl-d4-Ce3 & & & \\
BGR4-cl-d5-Ce2 & & & \\
VKP1-sc-d4-Ce2 & Nt & \\
VKP5-scl-d4-De3 & & & \\
VKP5-scl-d3-De2 & & & \\
VKP7-sl-d2-De3 & & & \\
VKP8-sl-d4-De3 & & & \\
\hline
\end{tabular}

On the overall, it is observed that topography, water retention and nutrient availability index are the major constraints limiting the growth and productivity of maize in the study area. It is possible that farmers would not be able to improve the yield of this crop in the short term due to the observed types and severity of constraints. The topography (i.e., slope of land) in the study area poses a serious constrain for maize production. The situation is further compounded by major factors like texture and $\mathrm{pH}$, which are two important factors that influence nutrient availability index of any soil resource area. However, land characteristics such as water availability index, oxygen availability, rooting condition and salt concentration are highly favourable for maize production. These do not pose any current threat to maize production in the study area. The findings of this study are in conformity with those earlier reported by [21] which stated that a rainfall of $900 \mathrm{~mm}$, soil depth of $100 \mathrm{~cm}, \mathrm{pH}$ range of 5.5 and well-drained soil are highly suitable for maize. Similar findings have also been reported by $[22,23]$ in similar agro-ecologies of India.

\subsubsection{Paddy}

According to the results presented in Table 7, all sixteen mapping units which account for about 734.2 ha $(96.5 \%)$, are marginally suitable (S3) for paddy and these have slight to moderate and severe limitations ranging from water availability index (rainfall), topography (slope), oxygen availability (soil drainage), and nutrient availability index (pH) (Fig. 6).

In three mapping units, viz., VKP5-scl-d3-Ce2, VKP5-scld4-Be2 and VKP6-scl-d4-Ce2, which account for 180.6 ha (23.7\%), water availability index (rainfall) poses a severe limitation. In SGH-c-d4-Be1, BGR1-sl-d4-Ce2, BGR2-cd5-Be1，BGR3-sl-d4-Ce3，VKP3-c-d5-Be1，VKP4-s1-d2- 
Be1, and VKP7-sl-d2-De3, which account for 397.8 ha (52.3\%), water availability index (rainfall) and nutrient availability index $(\mathrm{pH})$ pose severe limitations. In BGR4-cld5-Ce2 and VKP1-sc-d4-Ce2, which account for 68.6 ha $(9 \%)$, water availability (rainfall) and oxygen availability (soil drainage) are severe limitations, whereas in MGL-cld3-De2, VKP5-scl-d4-De3, VKP5-scl-d3-De2, and VKP8sl-d4-De3, which account for 87.2 ha $(11.5 \%)$, water availability index (rainfall) and topography (slope) are severe limitations. Nutrient availability is the most severe constraint for paddy production in the study area. However, the use of integrated soil fertility management which incorporates mineral fertilizers, organic manures and improved germplasm could help to ameliorate the situation. This is however possible if farmers have the access and capability to manage the system.

According to earlier study by [24], annual rainfall of 1000 $\mathrm{mm}$ or more and fine textured soils with cambic/argillic horizons and fine textured silty clay loam are highly suitable for paddy. From the results obtained in this study, it is very clear that paddy production in the study area may be hampered by several limiting factors. Overall, oxygen availability (soil drainage) is a moderate to severe limitation; topography (slope), rooting condition (soil depth), water retention (soil texture) and nutrient availability index $(\mathrm{pH})$ are slight to moderate and severe limitations; whereas water availability index (rainfall) is a very severe limitation for paddy production in the study area. The study area may not be a highly recommended one for paddy due to the varying degree of limiting factors especially water availability index which is a severe limiting factor. Attention must be given to addressing these constraints if farmers in the study area are to realize encouraging yield levels on a sustainable basis. Sustainable small-scale irrigation could be one possible ameliorating strategy. Therefore, farmers growing paddy should take note of these constraints if high yields are to be achieved. Similar findings have also been reported by [22, 25] for neighbouring agro-ecologies.

Table.7: Land suitability for paddy

\begin{tabular}{cccc}
\hline & Land suitability class & \multicolumn{3}{c}{ Area } \\
\cline { 3 - 4 } Soil mapping unit & & 180.6 & 23.7 \\
\hline VKP5-scl-d3/Ce2 & S3w & \\
Vkp5-scl-d4/Be2 & & & \\
VKP6-cl-d4/Ce2 & & & \\
\hline BGR1-sl-d4-Ce2 & & 397.8 & \\
BGR2-c-d5-Be1 & & & \\
BGR3-sl-d4-Ce3 & S3wnai & \\
VKP3-c-d5-Be1 & & & \\
VKP4-sl-d2-Be1 & & & \\
VKP8-sl-d2-De3 & & & \\
SGH-c-d4-Be1 & & & \\
\hline BGR4-cl-d5-Ce2 & & \\
VKP1-sc-d4-Ce2 & & & \\
\hline MGL-cl-d3-De2 & & & \\
VKP5-scl-d4-De3 & & & \\
VKP6-scl-d3-De2 & & & \\
VKP9-sl-d4-De3 & & & \\
\hline
\end{tabular}




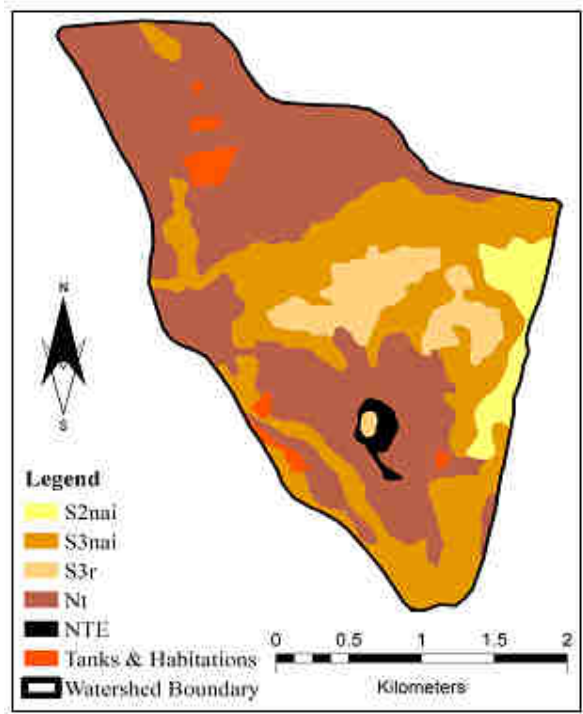

Fig. 5: Land suitability map for maize

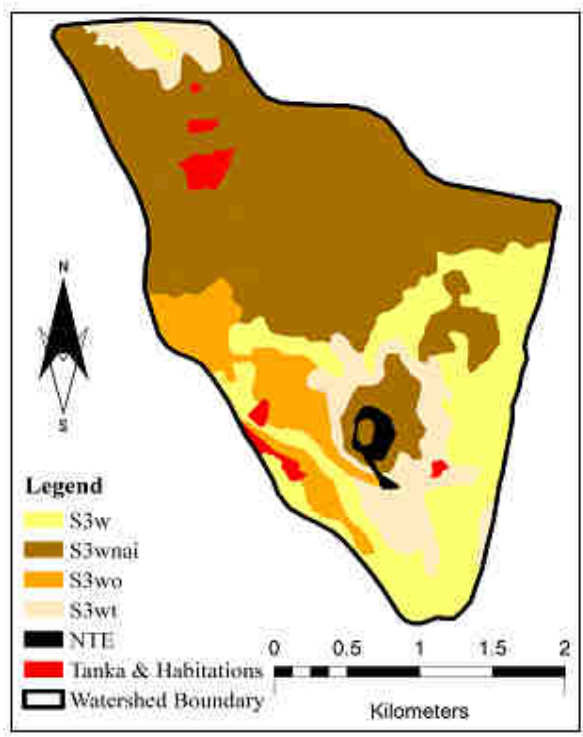

Fig. 6: Land suitability map for paddy

\section{CONCLUSION}

Land suitability assessment of study area has revealed that among the seven selected land qualities, five of them, namely water availability index (W), oxygen availability $(\mathrm{O})$, nutrient availability index (NAI), rooting conditions $(\mathrm{R})$, and topography (T) are the most limiting factors for sustainable maize and paddy production in the study area. Water retention (I) and excess of salts (Sa), do not pose any current threat to growing maize and paddy in the study area. Overall, 33.8 ha $(4.4 \%)$ of study area is moderately suitable, 312.7 ha $(41.1 \%)$ is marginally suitable, and 387.7 ha $(51 \%)$ is not suitable $(\mathrm{N})$ for maize; whereas for paddy, about 734.2 ha which makes up $96.5 \%$, is marginally suitable. The results of this study could be used to provide the baseline information needed for mapping specific soil resource constraints for sustainable production of these crops in the study area. Therefore, the integration of remote sensing \& GIS techniques could be envisaged as a laudable resource sustainable approach to model the growth of these crops in order to enhance profitable land use planning decision support for sustainable crop production in the study area. However, this cannot be achieved without the active involvement of the local farmers.

\section{REFERENCES}

[1] FAO, Guidelines: Land Evaluation for Rainfed Agriculture. Soils Bulletin No.52 Rome: 237, 1993.

[2] P. K. Garg, Development of a catchments scale erosion model for semiarid environment and its implementation through remote sensing. $\mathrm{PhD}$ thesis. University of Bristol, UK, 1991.

[3] S. Aronoff, Geographic Information System. A Management Perspective. WLD Publications, Ottawa, ON, Canada, 1991.

[4] J. B. Campbell, Introduction to Remote Sensing. The Guilford Press, New York, 1987.

[5] K. Green, Using GIS to predict fire behaviour. J Forestry 93: 21-25, 1995.

[6] J. C. Hinton, GIS and RS integration for environmental applications. Intern J Geo Info Sys 10: 877-890, 1996.

[7] FAO, A framework for land evaluation. FAO Soils Bulletin 32, Rome. 72p, 1976.

[8] M. K. Denis Amara, P. L. Patil, G. S. Dasog, M. V. Manjunath, Rainfall Erosivity (R-Factor) Estimation for Singhanhalli-Bogur Microwatershed in Northern Transition Zone of Karnataka. Res. J. Agric. Sci., 4 (5/6): 644-647, 2013.

[9] M. K. Denis Amara, P. L. Patil, Mapping of biophysical constraints of soils in semi-arid northern transition zone of India by GIS techniques. Int. J. Interdisciplinary and Multidisciplinary Studies (IJIMS), 2 (1): 68-80, 2014.

[10] Soil Survey Staff, Soil survey manual. Soil Conservation Service. U.S. Department of Agriculture Handbook 18, Washington D.C., USA, 2000.

[11] Soil Survey Staff, Keys to Soil Taxonomy, United States Department of Agriculture Natural Resource Conservation Service, $12^{\text {th }}$ Edition, Washington D.C., USA, 2014.

[12]FAO, Land evaluation for irrigated agriculture. FAO Soils Bulletin 55, Rome, 1985. 
[13] J. L. Sehgal, Pedology - Concepts and Application, Kalyani Publishers, New Delhi, 1996.

[14]C. Mongkolsawat, W. Putklang, S. Noppitag, Land Suitability for Rice in Northeast Thailand. Proceedings of The THEOS Satellite Space Technology for the Development of GIS, Chonburi, September 8-9, 2009.

[15] USDA, Soil survey manual USDA agricultural Hand book No 18. Oxford \&IBM publishing co, 1951.

[16]D. J. Radcliffe, L. Rochette, Maize in Anonia: An analysis of factors production. FAO/UNDP Project Land and Water Use Planning. (Field Report No 30). Rome, Italy: Maputo. Regional Centre GeoInformatics and Space Technology, Khonkean University Northeast Thailand. (2009). Application of Multi-temporal RADARSAT data to delineate the recurring flood extent, Final Report submitted to GISTDA, 1982.

[17] C. Sys, V. Ranst, J. Debaveye, Land Evaluation Part III, crop requirements. Agricultural publication No.7, ITC Ghent, 1993.

[18]C. Mongkolsawat, S. Paiboonsak, U. Chanket, Soil Erosion Risk Northeast Thailand: A Spatial Modeling. Proceedings of the International Conference on Space Technology \& Geo-informatics 2006 in Conjunction with National Conference on Mapping and Geoinformatics 2006, 5-8 November 2006, Ambassador City Jomtien Hotel, Chonburi Province, Thailand, 2006.

[19] L. G. K. Naidu, V. Ramamurthy, O. Challa, R. Hedge, P. Krishnan, Manual on Soil Suitability Criteria for Major Crops. Technical Bulletin, NBSS\&LUP Publ. 129, 2006.

[20]FAO, Feeding the World Sustainable Management of Natural Resources Fact sheets. Rome, Italy, 2008.

[21] J. D. Giri, R. L. Shyampura, J. L. Sehgal, Soil-site suitability for maize in Banswara district, Rajasthan. Agropedology, 4: 75-79, 1994.

[22] V. Mini, P. L. Patil, G. S., Dasog, Characterization and classification of soils of Pilot site in coastal agroecosystem of North Karnataka. Agropedology, 17(1): 59-67, 2007.

[23] R. Kumar, P. K. Mehra, B. Singh, H. S. Jassal, B. D. Sharma, Crop suitability analysis for crop diversification in the sub-mountain zone -A case study. J. Res., 46 (3/4): 153-162, 2009.

[24]T. P. Verma, R. V. S. Rao, S. K. Mahapatra, Evaluation of soil-site suitability for rice in humid subTropical areas of Hoogly district of West Bengal, Annals of Agric. Res., 20 (2): 183-185, 1999.
[25] M. A. RaviKumar, P. L. Patil, G. S. Dasog, Land Evaluation of 48A Distributary of Malaprabha Right Bank Command of Karnataka for Sustainable Land Use Planning. Karnataka J. Agric. Sci., 22(1): 89-94, 2009. 